\title{
Cystic Fibrosis in the Leeds Region: Incidence and Life Expectancy
}

\author{
R. J. PUGH ${ }^{\star}$ and J. D. PICKUP \\ From the Leeds Regional Paediatric Club
}

\section{Incidence}

A prospective survey of the incidence of cystic fibrosis among the 3 million population served by the Leeds Regional Hospital Board (L.R.H.B.) was begun in 1952 by all the paediatricians concerned. New births from January 1, 1952, to December 31, 1962 , were the subjects of the study, and every effort was made to discover and record patients with cystic fibrosis who evolved from this group (Table I).

During the 11 years 132 patients with cystic fibrosis were confirmed among the 546,764 births; an incidence of $1 / 4142$ or 0.241 per 1000 .

TABLE I

Number of Births 1952-1962 and Number With Cystic Fibrosis

\begin{tabular}{c|c|c}
\hline Year & $\begin{array}{c}\text { Births in L.R.H.B. } \\
\text { Area }\end{array}$ & $\begin{array}{c}\text { No. with Cystic } \\
\text { Fibrosis }\end{array}$ \\
\hline 1952 & 46,866 & 5 \\
1953 & 47,632 & 10 \\
1954 & 45,971 & 12 \\
1955 & 45,776 & 8 \\
1956 & 48,211 & 8 \\
1957 & 50,413 & 16 \\
1958 & 49,825 & 15 \\
1959 & 49,824 & 10 \\
1960 & 52,388 & 17 \\
1961 & 53,817 & 11 \\
1962 & 56,041 & 132 \\
\hline $1952-1962$ & 546,764 & \\
\hline
\end{tabular}

If the area is considered in three parts, located in the three Ridings of Yorkshire, a relatively lower incidence is found in the West Riding portion, which may indicate less complete ascertainment and suggest that the higher figure of $1 / 3000$ births prevailing in the East and North Ridings is more accurate (Table II).

The figure of 1 in 3000 will inevitably be an

Received December 12, 1966.

* Present address: Victoria Hospital for Sick Children, Park Street, Hull.
TABLE II

Regional Variation in Incidence

\begin{tabular}{|c|c|c|c|}
\hline & & $\begin{array}{c}\text { Births } \\
1952-1962\end{array}$ & $\begin{array}{l}\text { No. with Cystic } \\
\text { Fibrosis }\end{array}$ \\
\hline $\begin{array}{l}\text { Part of West Riding in } \\
\text { L.R.H.B. area } \cdots \\
\text { Part of North Riding in } \\
\text { L.R.H.B. area } \\
\text { Whole of East Riding in } \\
\text { L.R.H.B. area . }\end{array}$ & $\begin{array}{l}\cdots \\
\cdots \\
\cdots\end{array}$ & $\begin{array}{r}417,739 \\
30,393 \\
98,632 \\
\end{array}$ & $\begin{array}{l}87(1 / 4800) \\
10(1 / 3000) \\
35(1 / 2800) \\
\end{array}$ \\
\hline Total & $\cdots$ & 546,764 & 132 \\
\hline
\end{tabular}

underestimate, since only cases in which the diagnosis was certain are included, and a few patients born after 1960 may yet be recognized to be affected.

\section{Survival}

The most impressive data relate to the high mortality during the first year of life when 56 patients died ( 44 in the first 6 months). Thereafter, survivors diminished relatively slowly with $5,5,3$, and 0 dying in the subsequent pre-school years. By July 1966, 75 of the 132 children had died, and of the 57 survivors 15 are aged 10 years or more. All require close medical supervision.

A life-table is shown in Table III. The first column shows the ages at which the diagnosis was confirmed. In many the diagnosis was made when the children were already seriously ill and so a life-table in which children were entered at age of diagnosis will overestimate mortality. If ascertainment was complete, then all patients could be entered at birth, as in column 5 , and the lifetable derived as shown in column 7 . This will underestimate the true mortality since it is likely that the patients not ascertained will, on the whole, be those more severely affected. Of the 132 children in this series, 12 presented with meconium ileus, though only 8 required operation. 
TABLE III

Life Expectancy

\begin{tabular}{|c|c|c|c|c|c|c|c|}
\hline 1 & $\begin{array}{c}2 \\
\begin{array}{c}\text { No. Entering } \\
\text { Series During } \\
\text { Period }\end{array}\end{array}$ & $\begin{array}{c}3 \\
\text { No. in Series } \\
\text { Alive at End } \\
\text { of Survey }\end{array}$ & $\begin{array}{c}4 \\
\substack{\text { No. Dying } \\
\text { During } \\
\text { Period }}\end{array}$ & $\begin{array}{l}\quad 5 \\
\text { No. Present in } \\
\text { Series at Start } \\
\text { of Period if All } \\
\text { are Entered at } \\
\text { Birth }\end{array}$ & No. at Risk & $\begin{array}{c}7 \\
\begin{array}{c}\text { Mortality per } \\
1000 \text { in Period } \\
\text { Shown }\end{array}\end{array}$ & $\begin{array}{c}8 \\
\text { Proportion of } \\
\text { 1000 Alive at } \\
\text { Start of Each } \\
\text { Period }\end{array}$ \\
\hline $\begin{array}{c}\text { Days } \\
0 \\
7 \\
\text { Months } \\
1 \\
2 \\
3 \\
6 \\
\text { Years } \\
1 \\
2 \\
3 \\
4 \\
5 \\
6 \\
7 \\
8 \\
9 \\
10\end{array}$ & $\begin{array}{r}9 \\
7 \\
\\
6 \\
13 \\
37 \\
26 \\
16 \\
16 \\
8 \\
2 \\
5 \\
1 \\
1 \\
1 \\
0 \\
0 \\
0\end{array}$ & $\begin{array}{r}0 \\
0 \\
0 \\
0 \\
0 \\
0 \\
0 \\
0 \\
1 \\
3 \\
9 \\
13 \\
4 \\
6 \\
5 \\
1 \\
2\end{array}$ & $\begin{array}{r}1 \\
5 \\
6 \\
8 \\
21 \\
15 \\
5 \\
5 \\
3 \\
0 \\
1 \\
1 \\
0 \\
2 \\
0 \\
1\end{array}$ & $\begin{array}{r}132 \\
131 \\
126 \\
120 \\
112 \\
91 \\
76 \\
71 \\
65 \\
59 \\
50 \\
36 \\
31 \\
25 \\
18 \\
17\end{array}$ & $\begin{array}{r}131 \cdot 5 \\
128 \cdot 5 \\
123 \cdot 0 \\
116 \cdot 0 \\
101 \cdot 5 \\
83 \cdot 5 \\
73 \cdot 5 \\
68 \cdot 0 \\
62 \cdot 0 \\
54 \cdot 5 \\
43 \cdot 0 \\
33 \cdot 5 \\
28 \cdot 0 \\
21 \cdot 5 \\
17 \cdot 5 \\
15 \cdot 5\end{array}$ & $\begin{array}{r}8 \\
39 \\
\\
46 \\
63 \\
175 \\
120 \\
\\
37 \\
38 \\
23 \\
0 \\
10 \\
13 \\
0 \\
40 \\
0 \\
25\end{array}$ & $\begin{array}{r}1000 \\
992 \\
953 \\
907 \\
844 \\
669 \\
\\
549 \\
512 \\
474 \\
451 \\
451 \\
441 \\
428 \\
428 \\
388 \\
388\end{array}$ \\
\hline
\end{tabular}

TABLE IV

\section{Population Surveys}

\begin{tabular}{|c|c|c|}
\hline Authors & & Incidence \\
\hline $\begin{array}{l}\text { Steinberg and Brown (1960), Ohio, } \\
\text { U.S.A. . . . . . . } \\
\text { Selander (1962), Sंweden ... . . } \\
\text { Kramm, Crane, Sirken, and Brown } \\
\text { (1962), Massachusetts, New Hamp- } \\
\text { shire, and Vermont, U.S.A. } \\
\text { Danks, Allan, and Anderson (1965), } \\
\text { Melbourne, Australia .. . . }\end{array}$ & $\begin{array}{c}\cdots \\
\cdots \\
\cdots \\
\ldots\end{array}$ & $\begin{array}{l}0 \cdot 25-0 \cdot 29 / 1000 \\
0 \cdot 11-0 \cdot 13 / 1000 \\
0 \cdot 42+/ 1000 \\
0 \cdot 41 / 1000\end{array}$ \\
\hline
\end{tabular}

\section{Comment}

Early estimates using post-mortem figures gave a high incidence, for example 1 in 600 (Andersen and Hodges, 1946), perhaps because of selective referral. Estimates based on hospital admissions related to child population served give probably better estimates but with a wide range of error, for example 0.1 to 1.0 per 1000 (Carter, 1952). These estimates draw attention to the importance of the condition in the community.

More accurate results have come from population surveys and some of these are listed in Table IV.

Our figure of $0.34 / 1000$ for East and North
Ridings is close to, though a little lower than, that of the last two surveys listed above.

The above account has been collated by R. J. Pugh and J. D. Pickup from details supplied by the members of the Leeds Regional Paediatric Club.

We wish to acknowledge the valuable help and advice given by Dr. C. O. Carter, particularly for the preparation of the life expectation chart. We are also indebted to the Cystic Fibrosis Research Foundation Trust for a grant which enabled this work to be completed.

The following paediatricians were responsible for patients concerned in this study. M. W. Arthurton and A. P. Roberts, Bradford; W. P. Sweetnam, Halifax/ Huddersfield; M. G. Philpott and R. J. Pugh, Hull; E. C. Allibone, M. F. G. Buchanan, and W. S. Craig, Leeds; J. D. Pickup, Pontefract; W. Henderson, York; C. S. Livingstone, Wakefield/Dewsbury.

\section{REFERENCES}

Andersen, D. H., and Hodges, R. G. (1946). Celiac syndrome. V. Genetics of cystic fibrosis of the pancreas with a consideration of etiology. Amer. F. Dis. Child., 72, 62.

Carter, C. O. (1952). Familial incidence. In Fibrocystic Disease of the Pancreas, ed. M. Bodian, p. 50. Heinemann, London.

Danks, D. M., Allan, J., and Anderson, C. M. (1965). A genetic study of fibrocystic disease of the pancreas. Ann. hum. Genet., 28, 323.

Kramm, E. R., Crane, M. M., Sirken, M. G., and Brown, M. L. (1962). A cystic fibrosis pilot survey in three New England States. Amer. F. publ. Hlth, 52, 2041.

Selander, P. (1962). The frequency of cystic fibrosis of the pancreas in Sweden. Acta paediat. (Uppsala), 51, 65.

Steinberg, A. G., and Brown, D. C. (1960). On the incidence of cystic fibrosis of the pancreas. Amer. F. hum. Genet., 12, 416. 